JFFI. 2019; 6(2) 368-373

www.jurnal.farmasi.umi.ac.id/index.php/fitofarmakaindonesia

\title{
ANALISIS KADAR TANIN TOTAL EKSTRAK ETANOL BUNGA CENGKEH (Syzygium aromaticum L.) MENGGUNAKAN METODE SPEKTROFOTOMETRI UV-VIS
}

\author{
Mamat Pratama*, Raiz razak, Vivien Sandra Rosalina \\ Fakultas Farmasi, Universitas Muslim Indonesia \\ *mamat.pratama@umi.ac.id
}

Submission Date: 26-05-2019; $\quad$ Review Completed: 05-06-2019; $\quad$ Accepted Date:15-06-2019

\begin{abstract}
Clove flower (Syzygium aromaticum L.) contain saponins, tannins, alkaloids, glycosides and flavonoids. The research aimed to qualitatively and quantitatively determine the existence of tannins in ethanol extract of clove flower by $U V$-Vis Spectrophotometry. The extraction process used was maceration using ethanol of $30 \%$ with the yield value of $4.26 \%$. The extract obtained was measured by UV-Vis Spectrophotometer at the maximum wavelength of $649.9 \mathrm{~nm}$ using tanic acid as the standard. The value of the measurement result of tannin content obtained in the ethanol extract of clove flower was $300.826 \mathrm{mg}$ TAE/g extract or $30.0826 \% \mathrm{~b} / \mathrm{b}$ TAE.
\end{abstract}

Keywords: tannin; tanic acid; clove flower; UV-Vis spectrophotometer

\section{PENDAHULUAN}

Indonesia merupakan salah satu negara yang dikenal sebagai gudangnya tumbuhan obat. Penelitian tentang khasiat tumbuhan obat Indonesia sudah banyak dilakukan, diantaranya berbagai jenis tumbuh-tumbuhan liar, buah-buahan, sayur-sayuran, tanaman pangan, rempah-rempah (Kusuma dkk, 2005, hh.2-7).

Diantara berbagai tanaman tersebut cengkeh merupakan salah satu tanaman yang popular dan digunakan di seluruh dunia sebagai bumbu. Cengkeh sendiri merupakan tanaman rempah yang termasuk dalam komoditas sektor perkebunan yang mempunyai peranan cukup penting antara lain sebagai penyumbang pendapatan petani dan sebagai sarana untuk pemerataan wilayah pembangunan serta turut serta dalam pelestarian sumber daya alam dan lingkungan. Pada mulanya bagian dari tanaman cengkeh yaitu bunga cengkeh hanya digunakan sebagai obat terutama untuk kesehatan gizi (Nurdjannah, 2004).

Adapun bagian utama cengkeh yang sering dijadikan sebagai bahan obat-obatan maupun rempah-rempah adalah bagian bunganya disebabkan adanya terdapat kandungan minyak atsiri sebesar 10$20 \%$, sedangkan tangkainya sebesar $5-10 \%$ dan $1-4 \%$ pada bagian daunnya. Secara tradisional bunga cengkeh banyak digunakan dalam dunia kedokteran karena berfungsi sebagai fungisidal, bakterisidal, analgesik, antioksidan dan antiinflamasi (Ketaren, 2008).
Menurut penelitian yang dilakukan oleh Chaniago (1980) dalam Nurdjannah (2004), sejak tahun 22 sebelum Masehi, cengkeh digunakan sebagai rempah-rempah, diantaranya di Tiongkok digunakan dalam upacara keagamaan yaitu dimasukan ke dalam peti mayat. Begitu juga bagi perwira yang ingin menghadap kaisar diharuskan mengunyah cengkeh, sedang di Persia cengkeh digunakan sebagai lambang cinta. Kemudian berkembang lagi dan sejak tahun 1980 cengkeh digunakan sebagai periang yaitu sebagai pencampur tembakau ditambah rempah-rempah (Kemala, 1988).

Secara empiris tanaman cengkeh banyak digunakan sebagai obat tradisional diantaranya sebagai pengobatan untuk sakit perut dengan cara mengunyah bunga cengkeh tersebut dan untuk sakit mata dengan meneteskan air perendaman bunga /cengkeh. Disamping itu cengkeh digunakan sebagai pembangkit nafsu makan, menyembuhkan kolik atau diberikan pada wanita yang baru melahirkan dalam bentuk ramuan dengan bahan bahan obat lainnya (Nurdjannah, 2004).

Dalam penelitian yang telah dilakukan bunga cengkeh kering mengandung minyak atsiri, fixed oil (lemak), resin, tanin, protein, cellulosa, pentosan dan mineral. Karbohidrat terdapat dalam jumlah dua per tiga dari berat bunga. Komponen lain yang paling banyak adalah minyak atsiri yang jumlahnya bervariasi tergantung dari banyak faktor diantaranya jenis tanaman, tempat tumbuh dan cara pengolahan (Purseglove et al., 1981). 
Telah dilakukan pemisahan kandungan kimia dari serbuk bunga, tangkai bunga dan daun cengkeh hingga didapatkan hasil bahwa serbuk bunga dan daun cengkeh mengandung saponin, tanin, alkaloid, glikosida dan flavonoid, sedangkan tangkai bunga cengkeh mengandung saponin, tannin glikosida dan flavonoid (Ferdinanti, 2001).

Tanin diketahui merupakan senyawa aktif metabolit sekunder yang mempunyai beberapa khasiat yaitu sebagai astringen, anti diare, anti bakteri dan antioksidan. Tanin merupakan komponen zat organik yang sangat kompleks, terdiri dari senyawa fenolik yang sukar dipisahkan dan sukar mengkristal, mengendapkan protein dari larutannya dan bersenyawa dengan protein tersebut (Desmiaty et al., 2008).

Tanin memiliki beberapa khasiat diantaranya menghentikan pendarahan dan mengobati luka bakar, menghentikan internal healing berjalan dan tanin mampu membuat lapisan pelindung luka dan ginjal. Tanin digunakan sejak lama sebagai pengobatan cepat diare, disentri, perdarahan, dan mereduksi ukuran tumor. Berbagai virus in aktif dengan paparan tanin (Saifudin dkk, 2011).

Maka berdasarkan penelitian diatas peneliti akan melakukan analisis kadar tanin tanaman bunga cengkeh dengan menggunakan metode spektrofotometri UV-VIS.

\section{METODE PENELITIAN}

\section{A. Pengambilan dan Pengolahan Sampel}

Sampel penelitian yang digunakan berupa bunga cengkeh (Syzigium aromaticum L.) yang diperoleh dari palu Sulawesi Tengah. Sampel bunga cengkeh yang dikumpulkan kemudian dibersihkan dan dicuci dengan air mengalir. Bunga cengkeh (Syzygium aromaticum L.) yang masih segar diambil dan dikumpulkan untuk kemudian dilakukan beberapa tahapan sebelum dibuat ekstrak, lalu dilakukan pencucian sampel untuk menghilangkan tanah dan pengotor lainnya yang melekat pada bahan simplisia, pencucian dilakukan dengan air bersih yang mengalir. Langkah selanjutnya adalah perajangan bahan simplisia untuk mempermudah proses pengeringan dan penggilingan. Lalu dilakukan pengeringan untuk mendapatkan simplisia yang tidak mudah rusak, sehingga dapat disimpan dalam waktu yang lebih lama. Pengeringan daun kopasanda yaitu dengan cara dijemur tanpa sinar matahari atau diangin-anginkan. Dan yang terakhir adalah pembuatan serbuk simplisia dilakukan dengan cara menghaluskan simplisia kering dengan menggunakan blender yang kemudian diayak.

\section{B. Pembuatan Ekstrak Sampel}

Pembuatan ekstrak bunga cengkeh (Syzygium aromaticum L.) dengan menggunakan metode maserasi. Serbuk bunga cengkeh (Syzygium aromaticum L.) ditimbang sebanyak 50 gram kemudian direndam dalam $150 \mathrm{~mL}$ etanol $30 \%$ selama 3 X 24 jam, kemudian disaring untuk mendapatkan filtrat dan residu. Residu di remaserasi kembali sebanyak 2 kali hingga diperoleh filtrat dari hasil penyaringan. kemudian diuapkan dengan Rotaryvaccum evaporator untuk mendapatkan ekstrak kasar bunga cengkeh (Syzygium aromaticum L.) kemudian dikeringkan menggunakan Freezdryer. C. Analisis Kualitatif Tanin

Sebanyak 2 gram ekstrak etanol bunga cengkeh (Syzygium aromaticum L.) ditambahkan dengan aquadest $100 \mathrm{~mL}$ dan dididihkan selama 15 menit, setelah itu ditambahkan $1 \mathrm{~mL} \mathrm{NaCl} 2 \%$ dan disaring. Filtrat dibagi 2 bagian $\mathrm{A}$ dan $\mathrm{B}$ di tambahkan 3 tetes pereaksi $\mathrm{FeCl}_{3} 5 \%$. Positif tanin apabila tebentuk warna hitam kebiruan.Filtrat B ditambahkan gelatin terbentuknya endapan putih (Mukhriani, Nonci, dan Mumang 2014, h.155).

\section{Analisis Kuantitatif Tanin}

Pembuatan larutan standar Asam tanat 1000 ppm Sebanyak $10 \mathrm{mg}$ asam tanat ditimbang kemudian dilarutkan dengan aquadest dalam gelas kimia. Selanjutnya dimasukkan dalam labu ukur 10 $\mathrm{mL}$ dan ditambah aquadest sampai tanda batas. Larutan tersebut dijadikan sebagai larutan induk 1000 ppm, dari larutan tersebut dibuat larutan standar dengan konsentrasi 10, 15, 20, 25, 30, 35 ppm. (Irianty dan Yenti 2014, hal.3).

Pembuatan Reagen Folin Denis

Sodium tungstate diambil sebanyak 5 gram dan dicampurkan dengan asam fosfomolibdat sebanyak 1 gram. Dilarutkan dengan menggunakan aquadest dalam gelas kimia. Setelah larut sempurna dimasukkan kedalam labu ukur $50 \mathrm{~mL}$ selanjutnya ditambahkan asam fosfat $2,5 \mathrm{~mL}$ dan ditambahkan quadest sampai tanda batas (Vermerris W dkk, 2006). Pembuatan larutan $\mathrm{Na}_{2} \mathrm{CO}_{3}$ jenuh

Pembuatan larutan $\mathrm{Na}_{2} \mathrm{CO}_{3}$ jenuh dilakukan dengan cara menimbang sebanyak 7,5 gram $\mathrm{Na}_{2} \mathrm{CO}_{3}$ kemudian dilarutkan dengan aquadest dalam gelas kimia dan dipanaskan pada suhu $60^{\circ} \mathrm{C}$. Setelah larut sempurna dimasukkan kedalam labu ukur $100 \mathrm{~mL}$ (Andriyani dkk, 2010).

Penetapan panjang gelombang serapan maksimum

Salah satu konsentrasi larutan baku diambil dan diukur serapannya pada rentang panjang gelombang 400-800 nm. Panjang gelombang yang menunjukkan nilai serapan tertinggi merupakan panjang gelombang maksimum. Berdasarkan pengukuran panjang gelombang yang telah dilakukan 
maka digunakan panjang gelombang maksimum 649,9 nm.

Pengukuran larutan standar asam tanat.

$$
\text { Larutan standar dari masing-masing }
$$
konsentrasi 10, 15, 20, 25, 30, 35 ppm diambil sebanyak $1 \mathrm{~mL}$ selanjutnya dicampur dengan $1 \mathrm{~mL}$ reagen Folin. Campuran dibiarkan selama 3 menit kemudian ditambah dengan $\mathrm{Na}_{2} \mathrm{CO}_{3}$ jenuh sebanyak $1 \mathrm{~mL}$ dan diletakkan di tempat yang tidak terkena cahaya selama 40 menit untuk proses homogenisasi. Setelah itu, dilakukan pengukuran dengan spektrofotometri sinar tampak pada panjang gelombang 649,9 $\mathrm{nm}$. Hasil pembacaan absorbansi yang diperoleh digunakan untuk pembuatan kurva kalibrasi standar terhadap konsentrasi dari larutan standar asam tanat.(Irianty dan Yenti, 2014).

Analisis kadar tanin

Sebanyak $1 \mathrm{mg}$ ekstrak etanol bunga cengkeh (Syzygium aromaticum L.) ditimbang dan dilarutkan dengan aquades sampai $10 \mathrm{ml}$ (100 ppm) dan dibuat replikasi sebanyak 3 kali. Masing-masing dari replikasi dipipet sebanyak $9 \mathrm{~mL}$ dan dilarutkan dengan aquades sampai $10 \mathrm{~mL}$ (90 ppm). Ditambahkan $1 \mathrm{~mL}$ pereaksi folin denis, didiamkan selama 3 menit, ditambahkan 1,0 ml larutan $\mathrm{Na}_{2} \mathrm{CO}_{3}$ jenuh dan diinkubasi selama 40 menit, kemudian dibaca serapannya pada panjang gelombang 649,9 nm (Irianty dan Yenti, 2014).

\section{HASIL DAN PEMBAHASAN}

Hasil Penelitian

Tabel 1. Hasil ekstraksi dan persen rendemen ekstrak etanol bunga cengkeh (Syzygium aromaticum L.)

\begin{tabular}{ccccc}
\hline Sampel & $\begin{array}{c}\text { Berat sampel } \\
(\text { gram })\end{array}$ & $\begin{array}{c}\text { Total pelarut } \\
(\mathbf{m L})\end{array}$ & $\begin{array}{c}\text { Berat ekstrak } \\
(\text { gram })\end{array}$ & $\begin{array}{c}\text { Rendemen } \\
\text { ekstrak (\%) }\end{array}$ \\
\hline Bunga cengkeh & 30 & 450 & 1,28 & 4,26 \\
\hline
\end{tabular}

Tabel 2. Hasil pengukuran absorbansi larutan pembanding Asam tanat menggunakan spektrofotometer UV-Vis pada panjang gelombang maksimum $649,9 \mathrm{~nm}$

\begin{tabular}{ccc}
\hline Konsentrasi (ppm) & Absorbansi & Absorbansi blanko \\
\hline 10 & 0,231 & 0 \\
15 & 0,337 & 0 \\
20 & 0,454 & 0 \\
25 & 0,587 & 0 \\
30 & 0,685 & 0 \\
35 & 0,843 & 0 \\
\hline
\end{tabular}

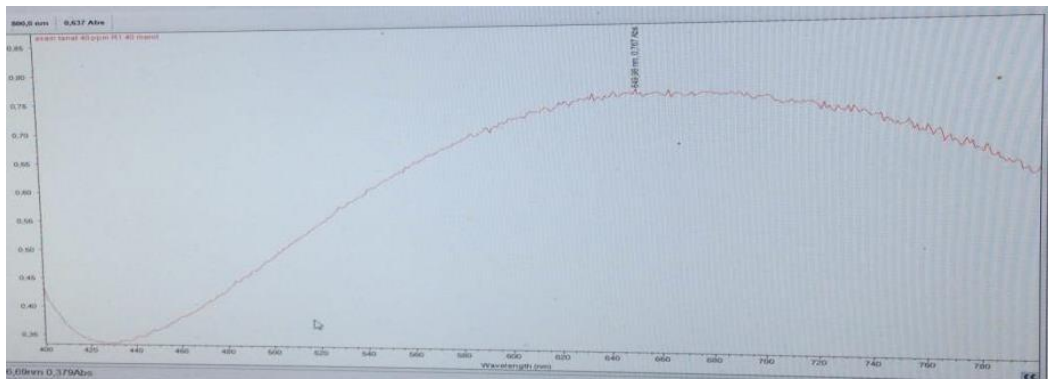

Gambar 1. Foto panjang gelombang maksimum 


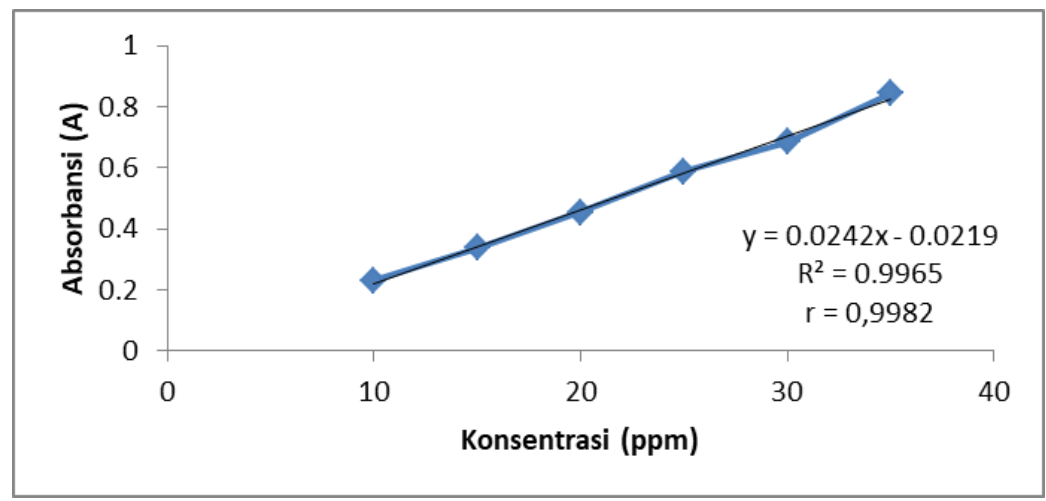

Gambar 2. Kurva baku asam tanat

Tabel 3. Penetapan kadar tanin total ekstrak etanol bunga cengkeh (Syzygium aromaticum L.)

\begin{tabular}{cccccccc}
\hline Replikasi & $\begin{array}{c}\text { Berat } \\
\text { ekstrak } \\
\text { (gram) }\end{array}$ & $\begin{array}{c}\text { Absorban } \\
\text { (Y) }\end{array}$ & $\begin{array}{c}\text { Absorban } \\
\text { kontrol } \\
\text { ekstrak }\end{array}$ & $\begin{array}{c}\text { Absorban } \\
\text { sampel } \\
\text { sesungguhnya }\end{array}$ & $\begin{array}{c}\text { Kandungan } \\
\text { tanin total }\end{array}$ & $\begin{array}{c}\text { kandungan } \\
\text { Tanin total } \\
\text { (mgTAE/g } \\
\text { Ekstrak) }\end{array}$ & $\begin{array}{c}\text { \% } \\
\text { Tanin } \\
\text { total }\end{array}$ \\
\hline 1 & 0,00103 & 0,640 & 0 & 0,640 & 292,098 & 300,826 & 30,082 \\
2 & 0,00106 & 0,680 & 0 & 0,680 & 300,984 & & \\
3 & 0,00104 & 0,686 & 0 & 0,686 & 309,396 & & \\
\hline
\end{tabular}

\section{Pembahasan}

Tanaman cengkeh sejak lama digunakan dalam industri rokok kretek, makanan, minuman dan obat-obatan. Bagian tanaman yang dapat dimanfaatkan untuk berbagai keperluan adalah batang, kulit batang, daun, tangkai, serta bunga cengkeh. Secara tradisional bunga cengkeh banyak digunakan dalam dunia kedokteran karena berfungsi sebagai fungisidal, bakterisidal, analgesik, antioksidan dan antiinflamasi. Serbuk bunga cengkeh sendiri mengandung saponin, tanin, alkaloid, glikosida dan flavonoid.

Tanin merupakan komponen zat organik yang sangat kompleks, terdiri dari senyawa fenolik yang sukar dipisahkan dan sukar mengkristal, mengendapkan protein dari larutannya dan bersenyawa dengan protein tersebut. Sifat tanin sebagai astringen dapat dimanfaatkan sebagai antidiare, menghentikan pendarahan, dan mencegah peradangan terutama pada mukosa mulut, serta digunakan sebagai antidotum pada keracunan logam berat dan alkaloid. Tanin dibedakan menjadi dua kelompok yaitu tanin terhidrolisis dan tanin terkondensasi.

Pada uji analisis kualitatif digunakan $\mathrm{FeCl}_{3}$ untuk menentukan apakah suatu sampel mengandung gugus fenol yang ditunjukkan oleh warna hijau kehitaman atau biru gelap setelah ditambahkan dengan $\mathrm{FeCl}_{3}$. Hasil yang didapatkan yaitu sampel berubah menjadi warna biru kehitaman. Dalam pengujian fitokimia dengan menggunakan pengujian dengan menggunaka pereaksi $\mathrm{FeCl}_{3}$ memberikan hasil positif, maka dapat disimpulkan bahwa sampel ekstrak etano bunga cengkeh (Syzygium aromaticum L.) mengandung senyawa fenolik dan salah satunya adalah senyawa tanin. Pembentukan tinta hijau atau biru-hitam pada ekstrak setelah ditambahkan dengan $\mathrm{FeCl}_{3}$ sebagai tanin akan membentuk kompleks dengan ion $\mathrm{Fe}_{3}{ }^{+}$(Harborne, 1987). Pada penambahan kalium ferrasianida dan ammonia ekstrak bunga cengkeh (Syzygium aromaticum L.) menghasilkan warna coklat tua. Hal itu mengindikasikan bahwa terdapat senyawa tanin. Pada ekstrak bunga cengkeh diketahui bahwa jenis tanin yang dimiliki yaitu tanin terhidrolisis karena memberikan warna biru hitam pada penambahan $\mathrm{FeCl}_{3}$.

Sebelum dilakukan analisis kuantitatif terlebih dahulu dilakukan penentuan panjang gelombang maksimum. Panjang gelombang maksimum $\left(\lambda_{\max }\right)$ adalah panjang gelombang pada saat serapannya maksimum dengan cara membaca serapan larutan standar asam tanat dan kemudian diubah-ubah panjang gelombangnya (Afrianto, 2008). Penetapan panjang gelombang maksimum bertujuan untuk mengetahui besarnya panjang gelombang yang dibutuhkan larutan asam tanat untuk mencapai serapan maksimum (Mulja dan Suharman, 1995). Diketahui hasil penetapan panjang gelombang serapan maksimum larutan standar asam tanat 30 ppm dengan panjang gelombang 649,9 nm. 
Selanjutnya dilakukan pembuatan kurva baku. Pembuatan kurva baku bertujuan untuk mengetahui hubungan antara konsentrasi larutan asam tanat dengan nilai nilai absorbansi sehingga konsentrasi sampel bunga cengkeh dapat diketahui. Larutan standar 1000 ppm dibuat seri konsentrasi 10, 15, 20, 25, 30 dan 35 ppm dan dibuat regresi linier seperti pada gambar 5. Persamaan kurva baku yang diperoleh dari konsentrasi asam tanat yaitu $\mathrm{y}=$ $0,0242 x-0,0219$ dengan nilai $r=0,9982$ digunakan untuk menetapkan kadar tanin bunga cengkeh (Syzygium aromaticum L.).

Pada uji kuantitatif dilakukan dengan menggunakan spektrofotometri UV-Vis pada panjang gelombang $190 \mathrm{~nm}-380 \mathrm{~nm}$ (pada daerah ultraviolet) atau panjang gelombang $380 \mathrm{~nm}-780 \mathrm{~nm}$ (pada daerah cahaya tampak). Untuk menentukan kadar tanin diukur dengan menggunakan kurva standar tanin. Standar tanin yang digunakan yaitu asam tanat. Pemilihan asam tanat dikarenakan asam tanat merupakan golongan tanin terhidrolisis sehingga dapat digunakan sebagai pembanding dalam pengukuran kadar tanin total (Supriyanto, R 2011). Tanin yang dibaca pada spektrofotmetri UVVis harus direaksikan dengan reagen pembentuk warna yaitu folin denis dan natrium karbonat. Pembentukan warnanya berdasarkan reaksi reduksi oksidasi, dimana tanin sebagai reduktor. Folin denis sebagai oksidator, tanin yang teroksidasi akan mengubah fosmolibdat dalam folin denis menjadi fosmolibdenim yang berwarna biru yang dapat menyerap sinar pada daerah panjang gelombang ultraviolet visibel (Andriyani D dkk, 2010). $\mathrm{Na}_{2} \mathrm{CO}_{3}$ bertujuan untuk membuat suasana basa agar terjadi reaksi reduksi folin denis oleh gugus hidroksil dari polifenol di dalam sampel dan akan membentuk kompleks molybdenum-tungsten berwarna biru.

Sampel di timbang sebanyak 3 kali dengan berat masing-masing 0,001 gram. Kemudian diukur dengan menggunakan spektrofotometri UV-Vis untuk mengetahui absorban dari sampel. Untuk mendapatkan absorban sampel sesungguhnya dilakukan dengan cara mengurangi nilai absorban sampel dengan nilai absorban kontrol ekstrak. Setelah di dapatkan absorban sampel sesungguhnya kemudian dihitung nilai kandungan tanin total masing-masing dari hasil replikasi sampel. Rata-rata kandungan tanin total nilai ekstrak dari sampel bunga cengkeh (Syzygium aromaticum L.) didapatkan dengan menjumlahkan keseluruhan nilai kandungan tanin total kemudian dibagi 3. Hasil yang didapatkan yaitu setiap gram ekstrak mengandung tanin sebesar $300,826 \mathrm{mg}$ TAE/g yang setara dengan asam tanat.

\section{KESIMPULAN}

Berdasarkan penelitian yang telah dilakukan di Laboratorium Kimia Farmasi Universitas Muslim Indioensia, maka dapat disimpulkan bahwa ekstrak etanol bunga cengkeh (Syzygium aromaticum L.) mengandung senyawa tannin. Adapun kadar tanin pada ekstrak etanol bunga cengkeh (Syzygium aromaticum L.) sebesar 300,826 mg TAE/g ekstrak atau $30,082 \%$ b/b TAE.

\section{DAFTAR PUSTAKA}

Andriyani, D, Utami, PI, Dhani, BA 2010, 'Penetapan kadar tanin daun rambutan (Nephelium lappaceum L.) secara spektrofotometri ultraviolet visibel', Jurnal Pharmacy, Vol.7 No. 02 Agustus 2010.

Afrianto, E 2008 Pengawasan Mutu Bahan/Produk Pangan jilid IIUntuk Sekolah Menengah Kejuruan, Direktorat Pembinaan SM, Jakarta.

Azwanida, N N 2015, A Review on the Extraction Methods Use in Medical Plants, Principle, Strength and Limitation, 4(3), Hal. 1-6.

Desinta, T 2015, 'Penentuan jenis tanin secara kualitatif dan penetapan kadar tanin dari kulit buah rambutan (Naphelium loppaceum L.) secara permanganometri', Calyptra: Jurnal Ilmiah Mahasiswa Surabaya Vol. 4 No. 1, hal. 3.

Desmiaty, Y, Ratih H, Dewi M.A, Agustin, R 2008, 'Penentuan Jumlah Tanin Total pada Daun Jati Belanda (Guazuma ulmifolia Lamk) dan Daun Sambang Darah (Excoecaria bicolor Hassk.) Secara Kolorimetri dengan Pereaksi Biru Prusia', Ortocarpus, 106-109.

Ferdinanti, E 2001, 'Uji Aktivitas Antibakteri Obat Kumur Minyak Cengkeh (Syzygium aromaticum (L) Merr \& Perry) Asal Bunga, Tangkai Bunga, dan Daun Cengkeh Terhadap Bakteri', Skripsi S1 Jurusan Farmasi, Fakultas Matematika dan Pengetahuan Alam, Institut Sains dan Teknologi Nasional Jakarta.

Fitrah, M 2016, 'Identifikasi ekstrak daun kopasanda (Chromolaena odorata L.) terhadap sel antiproliferasi tikus leukimia L1210', JF FIK UINAM Vol.4 No.3, hal.100-101.

Gandjar, IG \& Rohman, A 2007, Kimia Farmasi Analisis, Pustaka Pelajar, Yogyakarta, hal. 240-241.

Gandjar, IG \& Rohman A, 2012, Kimia Farmasi Analisis, Pustaka Pelajar. Yogyakarta, hal.252-256.

Hagerman, AE 2002, Tannin Handbook, Department of Chemistry and Biochemistry, Miami University. 
Hanani, E 2015, Analisis Fitokimia, EGC, Jakarta, hal. 79-81.

Harborne, 1987, Metode Fitokimia Penuntun Cara Modern Menganalisis Tumbuhan, trans. Padmawinata K, Soediro E, ITB Press, Bandung, Terjemahan dari: Phytochemical methods.

Integrated Taxonomic Information System, 2018, Syzygium aromaticum L., diakses pada 25 Mei 2018.http://itis.gov/.

Irianty, RS, Yenti, SR 2014, 'Pengaruh perbandingan pelarut etanol-air terhadap kadar tanin pada sokletasi daun gambir (Uncaria gambir Roxb)', SAGU, Maret 2014 Vol.13 No.1:17, ISSN 1412-4424, hal.3.

Kardinan, A 2003, Tanaman Pengusir dan Pembasmi Nyamuk, Agro Media Pustaka, Jakarta, hal.22-23.

Ketaren, 2008, Konsep dan Penerapan Metode Penelitian Ilmu Keperawatan, Salemba Medika, Jakarta.

Kusuma, FR, \& Zaky, B Muhammad 2005, Tumbuhan Liar Berkhasiat Obat, Agromedia, Jakarta, hal.2-7.

Maiola, MC, Mahendradatta, M, Laga, A, Djide, N 2013, 'Tanin extract of guajava leaves (Psidium guajava L.) variation with concentration organic solvent', International journal of scientific \& technology research Vol.2, ISSUE 9, ISSN 2277-8616, hal.107.

Maryani H, Suharmiati2006, Tanaman Obat Untuk Mengatasi Penyakit Pada Usia Lanjut, AgroMedia Pustaka, Jakarta.

Mukhriani, Nonci, FY, Mumang 2014, 'Penetapan kadar tanin total ekstrak biji jintan hitam (Nigella sativa) secara spektrofotometri UVVis', JK FIK UINAM Vol.2. No.4.

Mulja, M, Suharman 1995, Analisis Instrumental, Airlangga University Press, Surabaya.

Nurhasanah,N2012, 'Isolasi Senyawa Antioksida Ekstrak Metanol Daun Kersen (Muntingia calaburaLinn)', S.Farm Skripsi, Fakultas MIPA, Universitas Achmad Yani,Cimahi.

Nurdjanah, N 2004, 'DiversifikasiPenggunaan cengkeh. Balai Besar Penelitian Dan Pengembangan Pasca Panen Pertanian Bogor'. [serial online].

Saifudin, Aziz, Viesa Rahayu, Hilwan, Yuda Teruna 2011, Standarisasi Bahan Obat Alam, Edisi I, Graha Ilmu, Yogyakarta.

Sarker, S. d, Latif, z, \& Gray, AI 2006, Natural Products S, D. Sarker, z. Latif, \&Gray, Natural Product isolation $\left(2^{\text {nd }}\right)$ ed, Vol 18, Towota (New jersey, Humana Press Inc), hal 6-10.
Sujarnoko, TUP 2012, Studi Meta-Analisis Efek Senyawa Metabolit Sekunder Tanin Terhadap Kualitas Silase, Institut Pertanian Bogor, hal.4-5.

Supriyatna, MW, M, Iskandar, Y, Febriyanti, RM 2014, Prinsip Obat Herbal Sebuah Pengantar untuk Fitoterapi, Deepublish, www.deepublish.co.id, hal. 35.

Supriyanto, R 2011, 'Studi Analisis Spesiasi Ion Logam Cr(III) dan Cr(VI) dengan Asam Tanat dari Ekstrak Gambirmenggunakan Spektofotometri UV-VIS', J.Sains MIPA, April 2011, Vol. 17, No1, ISSN 1978-1873.

Tersono, L.A 2006, Tanaman Obat \& Jus untuk Asam Urat dan Rematik, AgroMedia Pustaka, Jakarta.

Thomas, A.N.S 2007, Tanaman Obat Tradisional, Kanisus, Yogyakarta.

Vermerris W, Nicholson, R 2006, Phenolic Compound, Springer Netherlands, hal.8890.

Waluyo, S2004, Aneka Tip Obat Alami dalam Buah dan Sayuran, Elex Media, Jakarta. 